\title{
Obituaries
}

Obituaries should be submitted by email to Kate Maynard at k.maynard@nature.com.

All submitted obituaries should be approximately 400 max words in length (apart from obituaries for past presidents of the BDA where the length should be 700-800 words)

Content of the obituary is down to the individual author, and the approval of the family should be given for the obituary prior

to submission to the BDJ.

\section{COLONEL (RETIRED)}

\section{BILL FLETCHER}

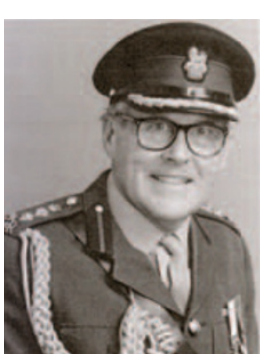

Colonel Bill Fletcher died aged 75 on 7 October 2007 after a long illness, borne with tremendous courage, strength and fortitude.

Born at Hartford on 9 December 1931

into a family with a strong military and dental background, Bill followed his father into dentistry and qualified from King's College Hospital in 1953. He was immediately called up for National Service in Korea for which he was awarded the UN Korean medal.

On completion of his National Service Bill joined his father and brother in law in a much respected practice in Bexleyheath and had a part time clinical lecturer appointment in the Prosthetics Department at the Royal Dental Hospital, London.

In 1964 Bill decided to rejoin the RADC. After a brief posting to Dental Centre Arborfield he was posted to BMH Benghazi. His tour in Libya was cut short by the six day war and Colonel Gaddafi's decision to rid himself of the British and so Bill was left with other medical officers to hurriedly close down the military hospital. After a tour in Sennelager Bill was posted as Senior Dental Officer to BMH Berlin.

Bill's next posting was to Northern Ireland as the first CO of 9 Dental Group. Bill and his wife Dorothy were attending a social function in the Military Wing of Musgrave Park Hospital when the building came under attack from missiles and they and other guests had to seek refuge under the dining table in order to avoid injury!
The next first for Bill was his posting to Hong Kong, then a series of Dental Group commands culminating in two of the most senior appointments in the Army Dental Service. Had the old order prevailed Bill would certainly have been a candidate for the rank of Brigadier. Bill retired from the Army in 1991.

Throughout his prolonged illness Bill had the devotion and support of his wife Dorothy and their children Jane, Anne, Peter and Kate.

A requiem Mass was held for Bill on 19 October 2007 at St Peter and St John Catholic Church Camberley. The church was packed to capacity by friends, relations and colleagues, a fitting tribute to someone the Corps held in such high esteem.

(Produced from the eulogy given by Brigadier [Retd] Ron Smart 'A Tribute to Bill')

J. H. H.

\section{GEOFFREY CHENEY}

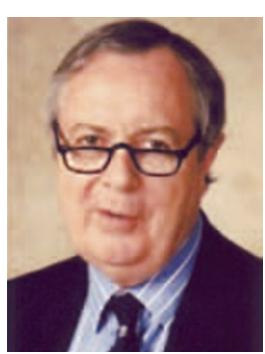

On 27 May 2008 family, friends and former colleagues gathered at St Margaret's Church, Hapton, Norfolk to say farewell to Geoffrey Cheney.

Geoffrey was

born in Hampshire in 1935, the youngest of five children. After leaving school he undertook his National Service in the Royal Navy. He then became a Midshipman and was seconded to HMS Ocean. Geoffrey was an officer on one of the support landing craft and amongst his many assignments was to go to the Woomera Rocket Range. He also witnessed the explosion of the American hydrogen bomb at Bikini Atoll. He retained his interest in the Navy with involvement in the Royal Naval Reserve and was awarded the Reserve Decoration.

In 1957 he entered Guy's Hospital Dental School. He qualified in 1962 and after a hospital post and a spell in general dental practice, he returned to Guy's in 1965 to study Medicine. He obtained his Dental Fellowship in 1967 and qualified medically in 1970. He was a Registrar at the Eastman Dental Hospital and later Senior Registrar on the East Grinstead/Guy's rotation.

In 1974 he was appointed Consultant Oral and Maxillofacial Surgeon at the Norfolk and Norwich Hospital. He was a most caring, conscientious and highly respected surgeon, who enjoyed a warm relationship with his colleagues. His most celebrated case, which was reported nationally, was the removal of a bullet that had become lodged behind the eye of Tenneh Cole, a little girl from Sierra Leone. Tenneh is now 19 years old, alive and well.

Geoffrey was Dental Tutor at Norwich for a number of years. He organised such excellent courses that practitioners travelled from far and wide to attend. In 1993 he was appointed Director of Postgraduate Dental Education in East Anglia, a post he held until retirement in December 2000.

Geoffrey was a great raconteur and loved entertaining. He enjoyed cooking and was very knowledgeable about wine. More recently he had taken up painting as a hobby.

Sadly, his wife Susie predeceased him. He leaves two step-children, Kate and Jeremy, of whom he was very proud, and four step-grandchildren

I should like to thank Mr G. Pell for allowing me to use extracts from his funeral address.

Janet M. Heath 